\title{
UPAYA PENINGKATAN KESELAMATAN LALU LINTAS DI RUAS JALAN NGAWI-MANTINGAN KABUPATEN NGAWI
}

\author{
Fitri Lutfiah Azizah ${ }^{1}$, Handa Lesmana ${ }^{2}$, Aryanti Fitrianingsih ${ }^{3 *}$

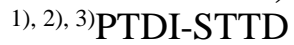 \\ *Email: aryantifitrianingsih1806@gmail.com
}

\begin{abstract}
Traffic safety is one of the important parts in traffic engineering to achieve traffic engineering safe, comfortable, and economical. Traffic accident is one of the biggest causes of death in Indonesia. The frequency of traffic accidents who lately tends to increase, not only caused by the human factor that is estimated to be the most influencing factor as the cause of the accident is seen from the infrastructure conditions of the course. In the accident which occurred on a road vehicle Ngawi-Mantingan more involved is the vehicle with motor. The way this is the access Ngawi-Mantingan solid enough because in the city by the movement's dominance on the area where the main line area of Surabaya-Yogyakarta where the alternative path between cities. Due to the geographical position of the road, it is Ngawi Mantingan trails transport goods from Central Java Province towards the East Java Province or vice versa. To reduce the high number of accidents and lack of safety on the road safety inspection performed then Ngawi-Mantingan way having regard to any factors that affect the crash on the road. The inspection activities aiming to learn road safety management one then needs to do a safety improvement effort at least can minimize or prevent the occurrence of traffic accidents from happening again.
\end{abstract}

Keywords: Road Safety Management, Human Error, and Traffic Safety

\begin{abstract}
ABSTRAK
Keselamatan Lalu Lintas merupakan salah satu bagian yang penting dalam rekayasa lalu lintas untuk mencapai tujuan teknik lalu lintas yang aman, nyaman, dan ekonomis. Kecelakaan lalu lintas merupakan salah satu penyebab kematian tebesar di Indonesia. Frekuensi kecelakaan lalu lintas yang akhir-akhir ini cenderung meningkat, bukan saja disebabkan oleh faktor manusia (human error) yang selama ini diperkirakan sebagai faktor yang paling mempengaruhi penyebab kecelakaan dilihat dari kondisi prasarana jalannya. Dalam kecelakaan yang terjadi di jalan Ngawi-Mantingan kendaraan yang lebih banyak terlibat adalah kendaraan barang dengan motor. Jalan Ngawi-Mantingan ini merupakan akses yang cukup padat karena di dominasi oleh pergerakan antar kota pada daerah yang dilalui jalur utama Surabaya-Yogyakarta dan daerah yang dilalui jalur alternatif antar kota. Karena posisi geografis Ngawi jalan Ngawi-Mantingan ini merupakan jalur lintas angkutan barang dari Propinsi Jawa Tengah menuju Propinsi Jawa Timur maupun sebaliknya. Untuk mengurangi tingginya angka kecelakaan dan rendahnya keselamatan pada jalan Ngawi-Mantingan maka dilakukan inspeksi keselamatan jalan dengan memperhatikan faktor-faktor apa saja yang mempengaruhi kecelakaan di jalan tersebut. Kegiatan inpeksi tersebut bertujuan untuk mengetahui Road Safety Management salah satunya maka perlu di lakukan upaya peningkatan keselamatan yang setidaknya dapat meminimalisir ataupun mencegah terjadinya kecelakaan lalu lintas terjadi lagi.
\end{abstract}

Kata Kunci: Road Safety Management, Human Error, dan Keselamatan Lalu Lintas

\section{PENDAHULUAN}

Permasalahan keselamatan lalu lintas jalan di Indonesia pada saat ini meliputi masalah umum, masalah operasional, masalah teknis, masalah sosial, dan lain-lain. Masalah umum yang ada pada keselamatan lalu lintas jalan yang ada di Indonesia saat ini adalah rendahnya kesadaran masyarakat terhadap ketertiban berlalu lintas di jalan, lemahnya sistem pengawasan dan pengendalian transportasi baik di jalan maupun di terminal. Permasalahan sosial dalam transportasi adalah rendahnya kesadaran dan kepedulian serta pengetahuan masyarakat terhadap keselamatan lalu lintas di jalan dan rendahnya kemampuan ekonomi pada sebagian besar masyarakat Indonesia, sehingga menyebabkan rendahnya disiplin dalam berlalu lintas di jalan yang pada akhirnya menjadi penyebab terjadinya kecelakaan lalu lintas. Kabupaten Ngawi dilintasi jalur utama Surabaya-Yogyakarta, jalur utama Cepu, Bojonegoro-Madiun dan menjadi gerbang utama Jawa Timur jalur selatan.

Kabupaten Ngawi seperti juga kota kabupaten lainnya di Jawa Timur memiliki karakteristik transportasi yang cukup unik, dimana tingkat pergerakan transportasi antar kecamatan hanya terlihat pada saat pagi hari terutama pergerakan anak sekolah, pergerakan para pekerja perkantoran yang 
memiliki waktu masuk, istirahat dan pulang yang tetap dan pergerakan pedagang yang dipengaruhi oleh jam pasar. Sedangkan, di luar itu pergerakan didominasi oleh pergerakan antar kota pada daerah yang dilalui jalur utama Surabaya-Yogyakarta dan daerah yang dilalui jalur alternatif antar kota karena posisi geografis Ngawi yang merupakan perlintasan pergerakan dari Provinsi Jawa Tengah ke Provinsi Jawa Timur (dan sebaliknya), dan sedikit pergerakan internal dalam masing-masing kecamatan dengan tujuan pergerakan ke sawah, ladang dan aktifitas pasar. Dengan adanya pergerakan internal-eksternal, eksternal-internal, eksternal-eksternal, dan internal-internal, maka akan menimbulkan dampak negatif yaitu mobilitas transportasi semakin tinggi dan juga tingkat kecelakaan lalu lintas akan tinggi.

Data kecelakaan yang diperoleh dari POLRES Kabupaten Ngawi yang menunjukkan korban meninggal dunia akibat kecelakaan lalu lintas tahun 2014 sebanyak 90 jiwa, tahun 2015 sebanyak 112 jiwa. Berdasarkan data primer yang didapatkan dari data kronologi kecelakaan dari Polres Kabupaten Ngawi dapat di ketahui daerah rawan kecelakaan yang dilihat dari tingkat keparahan korbannya dan dirangkingkan berdasarkan pembobotan sehingga di dapat 13 ruas jalan yang dijadikan ruas jalan rawan kecelakaan. Dari ketiga belas ruas jalan tersebut, ruas jalan NgawiMantingan merupakan ruas jalan dengan perangkingan tingkat kecelakaan yang tertinggi di Kabupaten Ngawi dengan jumlah bobot korban meninggal dunia (MD) 72, korban luka berat (LB) 18, korban luka ringan (LR) 112 dengan total bobot korban kecelakaan sebesar 202. Kejadian kecelakaan di jalan tersebut dikarenakan kendaraan yang melewati jalur ini melaju dengan rata-rata kecepatan tinggi dan jalan yang menikung dengan geometrik jalan menurun serta jarak pandang yang terhalang pohon dikarenakan tata guna lahan disekitar adalah hutan.

Dengan berbagai kondisi tersebut maka perlu adanya penelitian lebih lanjut untuk mengatasi masalah rendahnya keselamatan di ruas jalan Ngawi-Mantingan dikarenakan tingginya kecelakaan dan menentukan upaya peningkatan keselamatan lalu lintas. Dari latar belakang dan informasi yang di dapat maka penulis ingin meneliti mengenai upaya peningkatan keselamatan lalu lintas di ruas jalan Ngawi-Mantingan Kabupaten Ngawi.

\section{KAJIAN LITERATUR}

\section{Kecelakaan Lalu Lintas}

Kecelakaan lalu lintas merupakan peristiwa yang terjadi secara tiba-tiba sehingga mengakibatkan kerugian material dan luka pada korbannya serta dapat berdampak pada lingkungan (Rune Elvik).

Menurut Pedoman Operasi Accident Investigation Unit/Unit Penelitian Kecelakaan Lalu Lintas, oleh Direktorat Jenderal Perhubungan Darat, Titik Rawan Kecelakaan atau Blackspot adalah lokasi pada jaringan jalan dimana frekuensi kecelakaan atau jumlah kecelakaan lalu lintas dengan korban mati, atau kriteria kecelakaan lainnya, per tahun lebih besar daripada jumlah yang ditentukan. Panjang Blackspot pada suatu ruas jalan adalah antara 100-300 meter.

Sedangkan menurut Pedoman Penanganan Lokasi Rawan Kecelakaan Lalu Lintas (2004) lokasi rawan kecelakaan adalah lokasi tempat sering terjadi kecelakaan lalu lintas dengan tolak ukur tertentu, yaitu ada titik awal dan ada titik akhir yang meliputi ruas (persimpangan) yang masing-masing mempunyai jarak panjang tertentu.

\section{Faktor Penyebab Kecelakaan}

Menurut Hobbs (1979), secara umum ada empat faktor penyebab kecelakaan lalu lintas, yaitu faktor pengguna jalan, misalnya kondisi fisik, keterampilan dan disiplin pengemudi maupun pejalan kaki; faktor kendaraan, misalnya kondisi teknis yang sudah tidak layak maupun penggunaannya tidak benar; faktor jalan, misalnya geometri jlaan yang tidak sempurna, kerusakan jalan, maupun kurangnya kelengkapan jalan; dan faktor lingkungan, misalnya cuaca yang buruk.

Dalam suatu peristiwa kecelakaan, dari keempat faktor tersebut tidak dapat dipersalahkan salah satu, karena biasanya saling mempengaruhi satu sama lain dan paling tidak ada dua faktor yang menyebabkan terjadinya suatu kecelakaan, karena pada dasarnya faktor-faktor tersebut berkaitan atau 
saling menunjang bagi terjadinya kecelakaan. Namun, dengan diketahuinya faktor penyebab kecelakaan yang utama dapat ditentukan langkah-langkah penanggulangan untuk menurunkan jumlah kecelakaan. Faktor kecelakaan dapat dikomposisikan sebagai berikut:

Tabel 1. Faktor Kecelakaan Lalu Lintas

\begin{tabular}{|c|c|c|}
\hline Faktor Penyebab & Uraian & Prosentase \\
\hline Pengemudi & $\begin{array}{c}\text { Lengah, mengantuk, tidak terampil, mabuk, kecepatan } \\
\text { tinggi, tidak menjaga jarak, kesalahan pejalan, gangguan } \\
\text { binatang. }\end{array}$ & 93,52 \\
\hline Kendaraan & $\begin{array}{c}\text { Ban pecah, kerusakan istem rem, kerusakan sistem } \\
\text { kemudi, as/kopel lepas, sistem lampu tidak berfungsi. }\end{array}$ & 2,76 \\
\hline Jalan & $\begin{array}{c}\text { Persimpangan, jalan sempit, akses yang tidak } \\
\text { dikontrol/dikendalikan, marka jalan kurang/tidak } \\
\text { berfungsi. }\end{array}$ & 3,23 \\
\hline Lingkungan & $\begin{array}{c}\text { Lalu lintas campuran antara kendaraan cepat dengan } \\
\text { kendaraan lambat, interaksi/campur antara kendaraan } \\
\text { dengan pejalan, pengawasan dan penegakan hukum } \\
\text { belum efektif, pelayanan gawat darurat yang kurang } \\
\text { cepat. Cuaca: gelap, hujan, kabut, asap }\end{array}$ & 0,49 \\
\hline
\end{tabular}

Analisa kecelakaan, keselamatan jalan dan pendidikan mengklasifikasikan faktor penyebab kecelakaan, yaitu:

a) Manusia

Kriteria pengemudi penyebab kecelakaan karena kelelahan, kejenuhan, usia, pengaruh alkohol, narkoba dan sejenisnya. Kriteria pejalan kaki lebih dikarenakan menyeberang tidak pada tempat dan waktu yang tepat, berjalan terlalu ketengah, dan tidak berhati-hati.

b) Kendaraan

Penyebab kecelakaan Karena kondisi teknis tidak laik jalan atau penggunannya tidak sesuai dengan ketentuan seperti rem blong, ban pecah, mesin tiba-tiba mati dan lain-lain.

c) Jalan

Faktor penyebab kecelakaan apabila terjadi kerusakan permukan jalan, seperti jalan berlubang, atua geometric jalan yang kurang sempurna seperti derajat kemiringan terlalu kecil atau besar pada suatu belokan sehingga pandangan pengemudi tidak bebas.

d) Lingkungan

Lingkungan merupakan salah satu yang dapat menyebabkan kecelakaan lalu lintas, tetapi bisa berhubungan dengan faktor penyebab kecelakaan lain terutama faktor manusia. Sebagian dari pengaruh lingkungan adalah cuaca, asap kendaraan ataupun dari industri dan pandangan sekitar.

1. Aspek Teknis

a) Kecepatan

Untuk menganalisis data kecepatan yang didapat dari survai spot speed digunakan analisis persentil $85\left(\mathrm{P}_{85}\right)$, ini digunakan untuk mengetahui batas kecepatan yang ditempuh oleh $85 \%$ kendaraan hasil survai. Menggunakan rumus sebagai berikut:

$$
\text { Persentil } 85=\left(B b+\frac{\left(\left(\frac{85}{100}\right) x n\right)-\sum f}{f \text { persentil }, i}\right) \underline{\mathrm{c}}
$$

Keterangan:

$\begin{array}{ll}\mathrm{Bb} & : \text { Batas Bawah Nyata Kelas dari kelas Persentil } \\ \mathrm{n} & : \text { Banyaknya Data } \\ \sum \mathrm{f} & : \text { Jumlah Frekuensi seluruh Kelas sampai dengan batas Kelas } \\ & \text { Persentil } \\ \mathrm{c} & : \text { Panjang Interval Kelas }\end{array}$


b) Diagram Tabrakan

Diagram tabrakan atau sering disebut diagram collision merupakan sketsa titik rawan kecelakaan yang memperlihatkan arah pergerakan kendaraan atau pejalan kaki pada saat terjadi tabrakan. Diagram ini menyediakan informasi tentang tipe serta jumlah kecelakaan termasuk kondisi hari kecelakaan, kondisi jalan saat terjadi kecelakaan, serta informasiinformasi penting lain tentang terjadinya kecelakaan. Di dalam diagram tabrakan kita dapat mengetahui pola yang jelas dri berbagai tipe tabrakan. Seperti tabrakan depan-depan, depansamping, depan-belakang, tabrakan beruntun, tabrakan tunggal, maupun tabrakan dengan pejalan kaki

c) Jarak Pandang

Jarak pandang merupakan panjang jalan di depan kendaraan yang masih dapat dilihat dengan jelas diukur dari titik kedudukan pengemudi. Adapun guna dari jarak pandang adalah untuk:

1) Menghindari terjadinya tabrakan pada kendaraan.

2) Memberi kesempatan pada suatu kendaraan untuk mendahului kendaraan lain yang melaju dengan kecepatan lebih rendah dengan menggunakan lajur di sebelahnya.

3) Menambah efisiensi suatu jalan, sehingga dapat meningkatkan volume pelayanan pada jalan semaksimal mungkin.

Sebagai pedoman bagi pengatur lalu lintas dalam penempatan rambu-rambu lalu lintas yang diperlukan pada setiap segmen jalan

d) Perlengkapan Jalan

Setiap jalan yang digunakan untuk lalu lintas umum wajib dilengkapi dengan perlengkapan jalan berupa rambu lalu lintas, marka jalan, alat pemberi isyarat lalu lintas, alat penerangan jalan, alat pengendali dan penaman pengguna jalan, alat pengawasan dan pengamanan jalan, fasilitas untuk sepeda, pejalan kaki, dan penyandang cacat, dan fasilitas pendukung kegiatan lalu lintas dan angkutan jalan yang berada di jalan di luar badan jalan.

e) Perhitungan Tingkat Kecelakaan Dengan Pembobotan

Dalam menentukan ruas rawan kecelakaan digunakan metode pembobotan, dimana masingmasing tingkat keparahan korban dikalikan masing-masing bobot yang sudah ditentukan sebelumnya agar didapat nilai yang seimbang untuk tiap tingkat keparahan. Hal ini dikarenakan bobot antara kecelakaan yang mengakibatkan korban meninggal dunia dengan korban luka berat atau luka ringan maupun hanya kerusakan saja tidak dapat disamakan, sehingga dapat diketahui ruas yang paling rawan kecelakaan adalah yang memiliki nilai bobot yang paling tinggi.

\section{METODE}

Penelitian dilaksanakan melalui berbagai tahapan berupa identifikasi masalah, pengumpulan data, pengolahan data dan hasil kesimpulan. Data yang digunakan berupa data sekunder dan data primer melalui pendekatan literaur yang berhubungan dengan penelitian. Analisis kemudian akan dilaksanakan kepada fasilitas perlengkapan jalan untuk memperoleh faktor-faktor penyebab kecelakaan.

\section{PEMBAHASAN}

\section{Data Kecelakaan dan Kronologi Kecelakaan Jalan Ngawi-Mantingan}

a) Data Kecelakaan dan Kronologi Kecelakaan Pada Segmen 1

1) Data Kecelakaan

Data kecelakaan di lokasi rawan kecelakaan pada segmen 1 yaitu data kecelakaan pada tahun 2015 yang didapatkan dari Kepolisian Kabupaten Ngawi. 
Tabel 2. Data Kecelakaan di Jalan Ngawi-Mantingan Pada Segmen 1

\begin{tabular}{|c|c|c|c|c|c|}
\hline No & Bulan & Jumlah Kejadian & MD & LB & LR \\
\hline 1 & Januari & 1 & & & 1 \\
\hline 2 & Februari & & & & \\
\hline 3 & Maret & 1 & & & \\
\hline 4 & April & & & & \\
\hline 5 & Mei & 2 & 1 & & 3 \\
\hline 6 & Juni & & & & \\
\hline 7 & Juli & 1 & 4 & 2 & 6 \\
\hline 8 & Agustus & 5 & 1 & & \\
\hline 9 & September & 1 & & & \\
\hline 10 & Oktober & & & & \\
\hline 11 & Nopember & & 2 & 1 & 2 \\
\hline 12 & Desember & 13 & 8 & 4 & 12 \\
\hline
\end{tabular}

Berdasarkan data kecelakaan Tahun 2015 diketahui jumlah total kejadian kecelakaan di ruas jalan Ngawi-Mantingan pada segmen 1 (satu) adalah sebanyak 13 (tiga belas) kejadian yaitu pada bulan Januari, Maret, Mei, Juli, Agustus, September, dan Desember. Dimana paling banyak kejadian yaitu pada bulan Agustus sebanyak 5 (lima) kejadian, dengan total korban 4 (empat) korban Meninggal Dunia (MD), 2 (dua) korban Luka Berat (LB), dan 6 (enam) korban Luka Ringan (LR).

b) Data Kecelakaan dan Kronologi Kecelakaan Pada Segmen 2

1) Data Kecelakaan

Data kecelakaan di lokasi rawan kecelakaan di Jalan Ngawi-Mantingan pada segmen 2 yang diperoleh dari Kepolisian Polres Kabupaten Ngawi Tahun 2015.

Tabel 3. Data Kecelakaan di Jalan Ngawi-Mantingan Pada Segmen 2

\begin{tabular}{|c|c|c|c|c|c|}
\hline No & Bulan & Jumlah Kejadian & MD & LB & LR \\
\hline 1 & Januari & 1 & & & 1 \\
\hline 2 & Februari & 1 & & & \\
\hline 3 & Maret & & & & \\
\hline 4 & April & & & & \\
\hline 5 & Mei & 1 & & & \\
\hline 6 & Juni & & & 1 & \\
\hline 7 & Juli & & & & 1 \\
\hline 8 & Agustus & 2 & 1 & & 1 \\
\hline 9 & September & 1 & & & \\
\hline 10 & Oktober & & & & \\
\hline 11 & Nopember & & & & \\
\hline 12 & Desember & 1 & 2 & 2 & 3 \\
\hline \multicolumn{7}{|l}{ Jumlah } & 7 & & & \\
\hline
\end{tabular}

Berdasarkan data kecelakaan Tahun 2015 diketahui jumlah total kejadian kecelakaan di ruas jalan Ngawi-Mantingan pada segmen 2 (dua) adalah sebanyak 7 (tujuh) kejadian yaitu pada bulan Januari, Februari, Mei, Agustus, September, dan Desember. Dimana paling banyak kejadian yaitu pada bulan Agustus sebanyak 2 (dua) kejadian, dengan total korban 1 (satu) korban Meninggal Dunia (MD), 1 (satu) korban Luka Berat (LB), dan 1 (satu) korban Luka Ringan (LR). 
c) Data Kecelakaan dan Kronologi Kecelakaan Pada Segmen 3

1) Data Kecelakaan

Data kecelakaan di lokasi rawan kecelakaan di Jalan Ngawi-Mantingan pada segmen 3 (tiga) yang diperoleh dari Kepolisian Polres Kabupaten Ngawi Tahun 2015.

Tabel 4. Data Kecelakaan di Jalan Ngawi-Mantingan Pada Segmen 3

\begin{tabular}{|c|c|c|c|c|c|}
\hline No & Bulan & Jumlah Kejadian & MD & LB & LR \\
\hline 1 & Januari & & & & \\
\hline 2 & Februari & & & & \\
\hline 3 & Maret & & & & \\
\hline 4 & April & 1 & & 1 & \\
\hline 5 & Mei & & & & \\
\hline 6 & Juni & & & & \\
\hline 7 & Juli & 1 & & & 1 \\
\hline 8 & Agustus & 1 & 1 & & 1 \\
\hline 9 & September & & & & \\
\hline 10 & Oktober & & & & \\
\hline 11 & Nopember & 1 & & & 1 \\
\hline 12 & Desember & & & & \\
\hline \multicolumn{7}{|l}{ Jumlah } & 4 & 1 & 1 & 3 \\
\hline
\end{tabular}

Berdasarkan data kecelakaan Tahun 2015 diketahui jumlah total kejadian kecelakaan di ruas jalan Ngawi-Mantingan pada segmen 2 (tiga) adalah sebanyak 4 (empat) kejadian yaitu pada bulan April, Juli, Agustus, dan Nopember. Dimana paling banyak kejadian yaitu 1 (satu) kejadian di setiap bulan tersebut.

d) Identifikasi faktor penyebab kecelakaan di segmen 1 (satu)

Tabel 5. Identifikasi Faktor Penyebab Kecelakaan di Segmen 1 (satu)

\begin{tabular}{|c|c|c|c|c|c|}
\hline \multirow{2}{*}{ Kecelakaan } & \multirow{2}{*}{ Penyebab } & \multicolumn{4}{|c|}{ Faktor } \\
\hline & & Manusia & Prasarana & Sarana & Lingkungan \\
\hline 1 & $\begin{array}{c}\text { Rambu Kurang Memadai, } \\
\text { Melawan Arus, Kecepatan Tinggi }\end{array}$ & V & V & & \\
\hline 2 & $\begin{array}{l}\text { Melawan Arus, Kecepatan Tinggi, } \\
\text { Jarak Pandang }\end{array}$ & V & V & & \\
\hline 3 & $\begin{array}{c}\text { Rambu Kurang Memadai, } \\
\text { Melawan Arus, Kecepatan Tinggi }\end{array}$ & V & V & & \\
\hline 4 & $\begin{array}{l}\text { Melawan Arus, Kecepatan Tinggi, } \\
\text { Jarak Pandang }\end{array}$ & V & V & & \\
\hline 5 & $\begin{array}{l}\text { Melawan Arus, Kecepatan Tinggi, } \\
\text { Jarak Pandang }\end{array}$ & V & V & & \\
\hline 6 & $\begin{array}{c}\text { Rambu Kurang Memadai, } \\
\text { Melawan Arus, Kecepatan Tinggi }\end{array}$ & V & V & & \\
\hline 7 & $\begin{array}{c}\text { Rambu Kurang Memadai, } \\
\text { Melawan Arus, Kecepatan Tinggi }\end{array}$ & V & V & & \\
\hline 8 & $\begin{array}{c}\text { Rambu Kurang Memadai, } \\
\text { Melawan Arus, Kecepatan Tinggi }\end{array}$ & V & V & & \\
\hline 9 & $\begin{array}{c}\text { Rambu Kurang Memadai, } \\
\text { Melawan Arus, Kecepatan Tinggi }\end{array}$ & V & V & & \\
\hline 10 & $\begin{array}{l}\text { Melawan Arus, Kecepatan Tinggi, } \\
\text { Jarak Pandang }\end{array}$ & V & V & & \\
\hline 11 & $\begin{array}{c}\text { Rambu Kurang Memadai, } \\
\text { Melawan Arus, Kecepatan Tinggi }\end{array}$ & V & V & & \\
\hline 12 & $\begin{array}{c}\text { Rambu Kurang Memadai, } \\
\text { Melawan Arus, Kecepatan Tinggi }\end{array}$ & V & V & & \\
\hline 13 & $\begin{array}{c}\text { Rambu Kurang Memadai, } \\
\text { Melawan Arus, Kecepatan Tinggi }\end{array}$ & V & V & & \\
\hline
\end{tabular}


Dari tabel identifikasi penyebab kecelakaan diatas dapat di simpulkan bahwa faktor manusia dan prasarana mendominasi terjadinya kecelakaan di ruas jalan Ngawi-Mantingan pada segmen 1 (satu).

e) Identifikasi faktor penyebab kecelakaan di segmen 2 (dua)

Tabel 6. Identifikasi Faktor Penyebab Kecelakaan di Segmen 2 (dua)

\begin{tabular}{|c|c|c|c|c|c|}
\hline \multirow{2}{*}{ Kecelakaan } & \multirow{2}{*}{ Penyebab } & \multicolumn{4}{|c|}{ Faktor } \\
\hline & & Manusia & Prasarana & Sarana & Lingkungan \\
\hline 1 & $\begin{array}{c}\text { Rambu Kurang Memadai, } \\
\text { Melawan Arus, Kecepatan } \\
\text { Tinggi }\end{array}$ & V & V & & \\
\hline 2 & $\begin{array}{c}\text { Rambu Kurang Memadai, } \\
\text { Melawan Arus, Kecepatan } \\
\text { Tinggi }\end{array}$ & V & V & & \\
\hline 3 & $\begin{array}{c}\text { Melawan Arus, Kecepatan } \\
\text { Tinggi, Jarak Pandang }\end{array}$ & V & V & & \\
\hline 4 & $\begin{array}{c}\text { Rambu Kurang Memadai, } \\
\text { Melawan Arus, Kecepatan } \\
\text { Tinggi }\end{array}$ & V & V & & \\
\hline 5 & $\begin{array}{c}\text { Rambu Kurang Memadai, } \\
\text { Melawan Arus, Kecepatan } \\
\text { Tinggi }\end{array}$ & V & V & & \\
\hline 6 & $\begin{array}{c}\text { Rambu Kurang Memadai, } \\
\text { Melawan Arus, Kecepatan } \\
\text { Tinggi }\end{array}$ & V & V & & \\
\hline 7 & $\begin{array}{c}\text { Rambu Kurang Memadai, } \\
\text { Melawan Arus, Kecepatan } \\
\text { Tinggi }\end{array}$ & V & V & & \\
\hline
\end{tabular}

Dari tabel identifikasi penyebab kecelakaan diatas dapat di simpulkan bahwa faktor manusia dan prasarana mendominasi terjadinya kecelakaan di ruas jalan Ngawi-Mantingan pada segmen 2 (dua).

f) Identifikasi ifikasi faktor penyebab kecelakaan di segmen 3 (tiga)

Tabel 7. Identifikasi Faktor Penyebab Kecelakaan di Segmen 3 (tiga)

\begin{tabular}{|c|c|c|c|c|c|}
\hline \multirow{2}{*}{ Kecelakaan } & \multirow{2}{*}{ Penyebab } & \multicolumn{4}{|c|}{ Faktor } \\
\hline & & Manusia & Prasarana & Sarana & Lingkungan \\
\hline 1 & $\begin{array}{c}\text { Rambu Kurang Memadai, } \\
\text { Melawan Arus, Kecepatan } \\
\text { Tinggi }\end{array}$ & V & V & & \\
\hline 2 & $\begin{array}{c}\text { Rambu Kurang Memadai, } \\
\text { Melawan Arus, Kecepatan } \\
\text { Tinggi }\end{array}$ & V & V & & \\
\hline 3 & $\begin{array}{c}\text { Rambu Kurang Memadai, } \\
\text { Melawan Arus, Kecepatan } \\
\text { Tinggi }\end{array}$ & V & V & & \\
\hline 4 & $\begin{array}{c}\text { Rambu Kurang Memadai, } \\
\text { Melawan Arus, Kecepatan } \\
\text { Tinggi }\end{array}$ & V & V & & \\
\hline
\end{tabular}

Dari tabel identifikasi penyebab kecelakaan diatas dapat di simpulkan bahwa faktor manusia dan prasarana mendominasi terjadinya kecelakaan di ruas jalan Ngawi-Mantingan pada segmen 3 (tiga).

\section{Analisis Keselamatan}

Berdasarkan data kecelakaan tahun terakhir dan hasil identifikasi penyebab kecelakaan beserta data yang dibutuhkan, dilakukan analisis pada masing-masing penyebab kecelakaan berdasarkan kronologi kejadian. Berikut adalah analisis pada lokasi rawan kecelakaan pada setiap segmen di ruas jalan Ngawi-Mantingan. 
Berdasarkan hasil analisis penyebab kecelakaan di titik lokasi rawan kecelakaan jalan NgawiMantingan, maka dapat di gambarkan hal apa saja yang perlu di lakukan untuk meningkatkan keselamatan, dimana dalam rekomendasi ini di lakukan perbaikan-perbaikan terhadap faktor-faktor yang menjadi penyebab kecelakaan pada ruas jalan Ngawi-Mantingan. Adapun faktor-faktor tersebut meliputi, jarak pandang yang sesuai dengan standar minimum jarak eksisting pada ruas jalan di masing-masing titik kecelakaan pada ruas jalan Ngawi-Mantingan dan juga melihat kondisi prasarana serta fasilitas perlengkapan jalan yang disesuaikan dengan standar yang sudah ada. Hal ini dilakukan guna mengurangi angka kecelakaan yang terjadi pada ruas jalan Ngawi-Mantingan. Berikut merupakan gambar usulan perbaikan yang perlu dilakukan pada ruas jalan Ngawi-Mantingan pada masing-masing titik kecelakaannya berdasarkan prasarana serta fasilitas perlengkapan jalannya.

a) Usulan Pada Segmen 1

Berdasarkan hasil analisa pada kondisi eksisting titik rawan kecelakaan di ruas jalan NgawiMantingan, maka dapat diketahui beberapa permasalahan yang menonjol dalam batasan masalah kajian di wilayah studi. Sehingga perlu diberikan rekomendasi yang diberikan kepada pemerintah daerah setempat dapat dilaksanakan. Berikut ini perlengkapan jalan yang perlu ditambahkan:

1) Mengurangi kecepatan kendaraan dengan memasang rambu batas kecepatan maksimal 60 $\mathrm{km} / \mathrm{jam}$.

2) Pemasangan lampu penerangan jalan umum yang tidak terdapat sama sekali dengan jarak 50 m pada tiap lampu.

3) Marka kewaspadaan atau pemasangan pita penggaduh (Rumble Strip), merupakan marka kewaspadaan dengan efek kejut tujuannya adalah menyadarkan pengemudi untuk berhatihati dan mengurangi kecepatan untuk meningkatkan keselamatan. Ukuran dan tinggi pita penggaduh ialah minimal 4 garis melintang dengan ketinggian 10-13 mm dan di tempatkan pada 50 meter sebelum tikungan di jalan Ngawi-Mantingan baik dari arah menuju Solo maupun arah menuju ke Kota.

b) Usulan Pada Segmen 2

Berdasarkan hasil analisa pada kondisi eksisting titik rawan kecelakaan di ruas jalan NgawiMantingan, maka dapat diketahui beberapa permasalahan yang menonjol dalam batasan masalah kajian di wilayah studi. Sehingga perlu diberikan rekomendasi yang diberikan kepada pemerintah daerah setempat dapat dilaksanakan. Berikut ini perlengkapan jalan yang perlu ditambahkan:

1) Rambu peringatan hati-hati, merupakan media yang diberikan untuk mengingatkan pengemudi untuk berhati-hati bahwasanya daerah tersebut sering terjadi kecelakaan. Posisi peletakan rambu rawan kecelakaan tersebut berada pada sisi kiri jalan NgawiMantingan arah menuju Solo, yang di posisikan 80 meter sebelum jembatan.

2) Pemasangan lampu penerangan jalan umum yang tidak terdapat sama sekali dengan jarak $50 \mathrm{~m}$ pada tiap lampu

c) Usulan Pada Segmen 3

Berdasarkan hasil analisa pada kondisi eksisting titik rawan kecelakaan di ruas jalan NgawiMantingan, maka dapat diketahui beberapa permasalahan yang menonjol dalam batasan masalah kajian di wilayah studi. Sehingga perlu diberikan rekomendasi yang diberikan kepada pemerintah daerah setempat dapat dilaksanakan. Berikut ini perlengkapan jalan yang perlu ditambahkan:

1) Pemasangan rambu peringatan hati-hati.

2) Pemasangan lampu penerangan jalan umum yang tidak terdapat sama sekali dengan jarak 50 m pada tiap lampu. 
Dari hasil analisis dan pembahasan pada bab sebelumnya, maka dapat disimpulkan bahwa kebutuhan ruas jalan di Jalan Ngawi-Mantingan adalah berupa fasilitas perlengkapan jalan pada tiaptiap segmen. Pada segmen 1 (satu) yaitu 1 (satu) rambu-rambu lalu lintas pembatas kecepatan dan 5 lampu penerangan jalan umum, pada segmen 2 yaitu 2 rambu peringatan hati-hati dan 5 lampu penerangan jalan umum, pada segmen 3 yaitu 1 (satu) rambu peringatan hati-hati dan 5 lampu penerangan jalan umum. Kemudiam berdasarkan data kecelakaan Tahun 2015 dari Kepolisian Lalu Lintas Kabupaten Ngawi, faktor-faktor penyebab kecelakaan di lokasi rawan kecelakaan pada Jalan Ngawi-Mantingan segmen 1, 2, dan 3 adalah faktor prasarana dan faktor manusia. Dari faktor manusia, perilaku pengguna jalan pada ruas jalan Ngawi-Mantingan tergolong rendah disiplin dan banyak melanggar peraturan, salah satu hal yang paling mempengaruhi adalah pengguna jalan berkecepatan tinggi dan melampaui batas kecepatan. Selain itu faktor penyebab terjadinya kecelakaan dari segi prasarana, adalah tidak sesuainya kondisi jalan eksisting dengan standar yang ada dan juga belum lengkapnya fasilitas perlengkapan jalan pada ruas jalan Ngawi-Mantingan.

\section{REFERENSI}

1. Republik Indonesia. 1991. Spesifikasi Lampu Penerangan Jalan Perkotaan. Direktorat Jenderal Bina Marga. Jakarta.

2. Republik Indonesia. 1993. Keputusan Menteri Perhubungan Nomor KM 60 Tahun 1993 tentang Marka Jalan.

3. Republik Indonesia. 1993. Keputusan Menteri Perhubungan Nomor KM 61 Tahun 1993 tentang Rambu-rambu Lalu Lintas Di Jalan.

4. Republik Indonesia. 1998. Analisa Kecelakaan. Keselamatan Jalan dan Pendidikan. Balai Diklat ALLAJR.

5. Republik Indonesia. 2004. Penanganan Lokasi Rawan Kecelakaan Lalu Lintas. Direktorat Jenderal Bina Marga. Jakarta.

6. Republik Indonesia. 2004. Undang-undang Nomor 38 tahun 2004 tentang Jalan. Direktorat Jenderal Bina Marga. Jakarta.

7. Republik Indonesia. 2008. Spesifikasi Penerangan Jalan Di Kawasan Perkotaan. Badan Standarisasi Nasional. Jakarta.

8. Republik Indonesia. 2009. Undang-undang Nomor 22 Tahun 2009 tentang Lalu Lintas dan Angkutan Jalan. Kementerian Perhubungan. Jakarta.

9. Republik Indonesia. 2011. Peraturan Pemerintah Nomor 32 Tahun 2011 tentang Manajemen dan Rekayasa. Analisis Dampak. serta manajemen Kebutuhan Lalu Lintas.

10. Republik Indonesia. 2013. Peraturan Menteri Perhubungan Nomor PM 34 tahun 2014 tentang Marka Jalan.

11. Republik Indonesia. 2014. Peraturan Menteri Perhubungan Nomor PM 13 Tahun 2014 tentang Rambu Lalu Lintas.

12. Republik Indonesia. 2015. Peraturan Menteri Nomor 26 Tahun 2015 tentang Standar Keselamatan Lalu Lintas dan Angkutan Jalan. Kementerian Perhubungan. Jakarta.

13. Republik Indonesia. Sukirman S. 1999. Dasar-dasar Perencanaan Geometri Jalan. Penerbit. Nova. Bandung. 